\title{
Standardization of drugs in emergency trolleys in intensive care and emergency units
}

Padronização de fármacos em carros de emergência nas unidades de terapia intensiva e emergência

Estandarización de medicamentos en coches de emergencia en las unidades de terapia intensiva y emergencia

Elizandra Cassia da Silva Oliveira*(D); Regina Célia de Oliveira** (D); Felicialle Pereira da Silva***(D);

Catarina Silva Nunes****(D)

\section{Abstract}

Background: The first Cardiopulmonary Resuscitation and Emergency Cardiovascular Care Guideline recommends the standardizing of the content of emergency trolleys to expedite healthcare to the patient in cardio-respiratory arrest (CRA).

Objective: To assess the standardization of drugs in emergency trolleys of 5 public hospitals in northeastern Brazil, according to the first Cardiopulmonary Resuscitation and Emergency Cardiovascular Guideline of the Brazilian Society of Cardiology.

Methodology: Cross-sectional, descriptive study with a quantitative approach in 44 emergency trolleys, analyzed from August 2015 to January 2016, presented in absolute and relative frequency.

Results: There was a shortage of recommended standardized drugs as well as expired validities at all priority levels. Non-standardized potentially dangerous drugs with expired validity were present.

Conclusion: The nonconformities in the standardization of drugs were evidenced in all assessed emergency trolleys, which may promote the occurrence of serious adverse events that have an impact on the patient's life.

Keywords: nursing; patient safety; cardiopulmonary reanimation; quality management; life support care

\section{Resumo}

Enquadramento: A primeira Diretriz de Ressuscitação Cardiopulmonar e Cuidados Cardiovasculares de Emergência recomenda a padronização do conteúdo dos carros de emergência a fim de agilizar o atendimento ao doente em paragem cardiorrespiratória (PCR).

Objetivo: Analisar a padronização de fármacos dos carros de emergência de 5 hospitais públicos no nordeste do Brasil, segundo a primeira Diretriz de Ressuscitaçáo Cardiopulmonar e Cuidados Cardiovasculares de Emergência da Sociedade Brasileira de Cardiologia.

Metodologia: Estudo transversal, descritivo, com abordagem quantitativa, em 44 carros de emergência, analisados no período de agosto de 2015 a janeiro de 2016, apresentados em frequência absoluta e relativa.

Resultados: Houve falta de fármacos padronizados recomendados, como também validades ultrapassadas em todos os níveis de prioridade. Fármacos potencialmente perigosos não padronizados e com validade ultrapassada estavam presentes. Conclusáo: As não conformidades na padronização de fármacos foi evidenciada em todos os carros de emergência estudados; o que pode favorecer a ocorrência de eventos adversos graves que têm impacto na vida do doente.

Palavras-chave: enfermagem; segurança do paciente; ressuscitação cardiopulmonar; gestão de qualidade em saúde; suporte avançado de vida

*MSc., Professor, University of Pernambuco, 50100-130, Recife, Brazil [elizandra.cassia@ bol.com.br]. (1) https://orcid.org/0000-0002-4785-4375. Contribution to the article: bibliographical research, data collection, statistical treatment and assessment, data analysis, discussion, and writing of the article. Address for correspondence: Estrada do Arrail, 2405, Tamarineira, Recife, Brasil.

**Ph.D., RN, University of Pernambuco, 50100-010, Recife, Brazil [reginac50@hotmail. com]. (D) https://orcid.org/0000-0002-6559-5872. Contribution to the article: statistical com]. (1) https://orcid.org/0000-0002-6559-5872. Contribution to the
treatment and assessment, discussion, and writing of the article.

treatment and assessment, discussion, and writing of the article.
****Ph.D., RN, Hospital da Restauracão, 52171-011, Recife, Brazil [cialle@ @hotmail.com]. ****Ph.D., RN, Hospital da Restauração, 52171-011, Recife, Brazil [cialle@ hotmail.com].
(D https://orcid.org/0000-0002-2805-7506. Contribution to the article: data analysis, and discussion and writing of the article.

*****ostgrad, RN, University of Pernambuco, 50100-010, Recife, Brazil [catynunes93@ hotmail.com]. (D) https://orcid.org/0000-0002-2902-4431. Contribution to the article: data collection and bibliographical research.

\section{Resumen}

Marco contextual: La primera directriz de Resucitación Cardiopulmonar y Cuidados Cardiovasculares de Emergencia recomienda la estandarización del contenido de los coches de emergencia para agilizar la atención al enfermo en paragem cardiorrespiratoria (PCR).

Objetivo: Analizar la estandarización de medicamentos de los automóviles de emergencia de 5 hospitales públicos en el noreste de Brasil según la primera Directriz de Resucitación Cardiopulmonar y Cuidados Cardiovasculares de Emergencia de la Sociedad Brasileña de Cardiología.

Metodología: Estudio transversal, descriptivo, con abordaje cuantitativo en 44 coches de emergencia, analizados en el período de agosto de 2015 a enero de 2016, presentados en frecuencia absoluta y relativa.

Resultados: La falta de medicamentos estandarizados recomendados, así como validez superada en todos los niveles de prioridad. Los medicamentos potencialmente peligrosos no estandarizados y con validez superada estaban presentes.

Conclusión: Las no conformidades en la estandarización de medicamentos fueron evidenciadas en todos los coches de emergencia estudiados; lo que puede favorecer la aparición de acontecimientos adversos graves que tienen impacto en la vida del paciente.

Palabras claves: enfermería; seguridad del doente; reanimación cardiopulmonar; gestión de la calidad; cuidados para prolongación de la vida

Received for publication: 26.04 .19

Accepted for publication: 23.06 .19

Série IV - n. ${ }^{\circ} 22$ - JUL./AGO./SET 2019 


\section{Introduction}

The cardio-respiratory arrest (CRA) is the unexpected interruption of cardiac and respiratory function, which requires sequential maneuvers and procedures to maintain cerebral and cardiopulmonary circulation in conditions that allow a better survival of the patient. However, to ensure the reversal of this event, actions, training of staff, and immediate availability of materials, equipment and drugs need to be standardized for safe and effective care delivery (Davies et al., 2014).

Thus, an artificial intravascular or endotracheal tube is often used for the infusion of fluids (colloids and crystalloids), collection of specimens, or administration of drugs, to restore the intravascular volume (Bowden $\&$ Smith, 2017). It is the nursing team's task to be responsible for the process of administration of fluids and drugs in situations of CRA. However, there is not sufficient evidence to determine the optimal time of administration of drugs, yet, its early initiation (within less than five minutes of CRA) is associated with a better prognosis of the patient (Gonzalez et al., 2013).

Within this context, the first Cardiopulmonary Resuscitation and Emergency Cardiovascular Care Guideline of the Brazilian Society of Cardiology, based on the Code Cart Statement of the American Heart Association, recommends standardizing the content of emergency trolleys (includes items for diagnostic evaluation, airway control, vascular access and circulatory control and drugs) in all units involved in care delivery to the sick person, to expedite the intervention against a possible CRA (Gonzalez et al., 2013). Thus, maximizing the efficiency of the use of emergency trolleys in situations of complications such as CRA is a vital responsibility for the health team, particularly for the nurse, who is also responsible for the systematic checking of the emergency trolley of his/her sector of activity, and should be aware that its ready-to-use status optimizes a quick and safe assistance.

Although the technological advances in equipment and procedures in emergency cardiovascular care are of high relevance, the pharmacological care at the time of a CRA stands out. The rush and stress during a CRA promote errors of administration of drugs when they are not quickly found, as well as their absence may lead to loss of time, reducing the success of care (Cid et al., 2017).

In the face of this relevance, this study aims to analyze the standardization of drugs of the emergency trolleys, according to the recommendation of the first Cardiopulmonary Resuscitation and Emergency Cardiovascular Care Guideline of the Brazilian Society of Cardiology, in intensive care units (ICU) and accident and emergency units (A\&E) of public hospitals in northeastern Brazil.

\section{Background}

The intra-hospital CRA in adults presents a worldwide incidence of 1.6/1,000 admissions, of which $52 \%$ occur in the ICU, with a survival rate of $18.4 \%$. However, in Brazil, in a multicenter study with 763 patients with CRA, 360 occurred in the ICU and in the coronary care unit, with a survival rate of $13 \%$ until hospital discharge, thus creating a better outcome for the CRA occurred in this sector (Silva, Silva, Silva, $\&$ Amaral, 2016). When the event occurs, immediate care is delivered by a multidisciplinary team, but also life support is provided, including the ready use of the emergency trolley.

However, the emergency sector is characterized as a sector with the high vulnerability of the occurrence of incidents related to medication errors, due to the highly rotating schedules and dynamic care delivery, associated with the quantitative and qualitative lack of material and human resources, work overload, and environmental and professional stress. Also, in the critical phase of emergency care, a large quantity of drugs is prescribed for intravenous administration, preferably, among which potentially dangerous drugs (PDD) are frequent (Mieiro et al., 2019). PDD can cause irreversible or fatal damage because of its improper use. Among medication errors, these are responsible for $80 \%$ of deaths. As preventive measures, the following steps must be carried out for this drug category: alert identification; disclosure list for the entire team; procedures and monitoring of their use and storage (Reis et al., 2018).

Generally, hospital institutions are complex systems that involve risks relating to the physical structure, use of technologies, and professionals involved in the provision of health care. These many risks include the process of administration 
of drugs, which is widely used in this context. Studies show that between $1.6 \%$ and $41.4 \%$ of hospitalized patients are affected by drug-related incidents, which may generate a cost of 25 to 30 million dollars in large hospitals (Valle, Cruz, \& Santos, 2017). However, in critical areas, due to the number of drugs and the severe status of the patient, these indices can be more evident (Valle et al., 2017). Thus, the administration of drugs is the last barrier to the incident. It should be prevented, so anticipating factors that can intercept it reduces this type of incident, assigned to the nursing team.

Since the emergency trolley is mainly used in cardiopulmonary resuscitation and in supporting other emergencies within the hospital setting, its daily check is cited as an excellent practice to be adopted by institutions for all services of hospital or pre-hospital care (Davies et al., 2014). According to the opinions of Brazilian nursing boards, the nurse is responsible for the daily organization, checking, and restocking of the emergency trolley, and can also be assisted by the nursing technician or assistant (Conselho Federal de Enfermagem, 2018; Conselho Regional de Enfermagem da Bahia, 2018).

The implementation of the checklist constitutes a valuable instrument to control the relationship of materials and drugs with their respective expirations and quantities, as well as the testing of equipment for intervention in an emergency (Bowden \& Smith, 2017).

Besides, the trolley must be clean and organized so that the drugs and equipment are available according to the ranking of priorities for use. Drawers should be identified with the description of their content. It is recommended that the trolley is positioned in a strategic location of easy access and mobility. It should also be sealed after verification of materials and drugs to ensure that it remains closed since the sealing should only be removed in situations of intervention in urgencies and emergencies, or when checking the trolley (Cid et al., 2017).

Regarding drugs, materials, and equipment essential for the intervention in the CRA (classified as level I), they should be immediately available for use: the highly recommended (classified as level II) in a maximum of 15 minutes after request, and the recommended items (classified as level III) are optional. Concerning the number of drugs and materials, it is up to each institution to standardize according to its need and institutional protocols (Gonzalez et al., 2013).

Thus, the non-compliance with these recommendations may interfere with the efficiency of the team during a CRA. It should be noted that studies carried out in countries such as the United Kingdom and the United States of America indicated that the attempts to revert a CRA were delayed due to the unavailability of drugs and equipment (Smith et al., 2008; Strzyzewski, 2006). Likewise, the emergency trolleys in Australian hospitals showed deficiencies in storage and maintenance of resuscitation equipment. Also, in a hospital in Botswana, a study indicated that the unavailability of emergency drugs and fluids in the imminence of a CRA could harm patient survival (Rajeswaran \& Ehlers, 2012).

In clinical practice, it has been observed that, during a CRA, the administration of drugs is performed primarily by the nursing team, which includes the identification, expiration date, preparation, and administration. This requires planning of actions, in addition to prior scientific knowledge, skills, and ethical competence (Costa et al., 2018). Thus, it should be stressed that the standardization of drugs in emergency trolleys should be implemented and monitored, promoting greater efficiency and quality in nursing care.

\section{Research Question}

The standardization of drugs in emergency trolleys in intensive care and accident and emergency units follows the recommendation of the first Cardiopulmonary Resuscitation and Emergency Cardiovascular Care Guideline of the Brazilian Society of Cardiology?

\section{Methodology}

An exploratory, descriptive study with a quantitative approach was developed in the ICU and A\&E sectors of five public teaching and researching hospitals located in the city of Recife, classified as large-scale and centers of excellence in the care of critical patients in the state of Pernambuco. These hospitals were identified 
as $\mathrm{H} 1, \mathrm{H} 2, \mathrm{H} 3, \mathrm{H} 4$, and $\mathrm{H} 5$.

The instrument used for data collection was a checklist, based on the first Cardiopulmonary Resuscitation and Emergency Cardiovascular Care Guideline of the Brazilian Society of Cardiology (Gonzalez et al., 2013). It should be noted that, the recommendations of the standardization of drugs of the emergency trolleys in the ICU and emergency sectors are matched. The independent variables were evaluated: availability and validity of the drug, location, and sealing of the emergency trolley.

The researcher adapted the checklist, and the research team applied it. Initially, a pre-test was conducted for the adequacy of the instrument during five days of data collection, including the training of the team. The checklist consisted of three parts: the first related to the identification of the hospital and unit (ICU or A\&E) and the observation period (date of data collection); the second part referring to the availability of drugs (present or absent) and their respective validity (within validity or validity expired); and the third part evaluated the location (accessible or not accessible) and the presence of sealing of the emergency trolley (present or absent). For the classification of PDD, the classification of the Institute for Safe Practices in the Use of Medication was used (Perini \& Anacleto, 2015). The study sample was constituted by census, composed of all emergency trolleys used in 2015 and 2016 in the ICU and A\&E units of these hospitals, 15 of them being located in $A \& E$ units and 29 in the ICU. According to the edicts GM/ MS no. 3432 of 12 August 1998 and SAS/MS no. 123 of 28 February 2005, the ratio of one emergency trolley, with a cardioverter/defibrillator, containing materials of intubation, drugs, and equipment for emergency care, for every 10 beds is necessary (Gonzalez et al., 2013).

The collection of data was carried out in pairs by the researchers, thus avoiding incorrect or doubtful data, during the routine hospital activities, without any previous notice and without harming the normal functioning of the unit. The collection of data occurred from August 2015 to January 2016, with the approval of the Ethics and Research Committee, in the opinion with the CAAE no. 434,841. The data were organized in an electronic database, using the program Excel ${ }^{\circ}$, version 2007, and analyzed descriptively, using absolute frequencies and percentages.

\section{Results}

The study assessed, according to the first Cardiopulmonary Resuscitation and Emergency Cardiovascular Care Guideline of the Brazilian Society of Cardiology, 44 emergency trolleys distributed in ICU and A\&E sectors. Table 1 shows that: regarding the location, $76.7 \%$ of the trolleys were in an easily accessible location; regarding the sealing, only $29.9 \%$ had it. However, only hospital $2(\mathrm{H} 2)$ presented all trolleys with an easily accessible location and sealing.

Table 1

Distribution of location and presence of sealing in the emergency trolleys

\begin{tabular}{lcccc}
\hline & \multicolumn{2}{c}{ ET location $(n=44)$} & \multicolumn{2}{c}{ ET sealing $(n=44)$} \\
$n(\%)$ & Not accessible & Present & Unavailable \\
\hline Assessed trolleys/hospital & Accessible & $1(16.6)$ & $0(0.0)$ & $6(100)$ \\
H1 $=6$ & $5(83.3)$ & $0(0.0)$ & $7(100.0)$ & $0(0.0)$ \\
H2 $=7$ & $7(100.0)$ & $12(54.5)$ & $1(4.5)$ & $21(95.5)$ \\
H3 $=22$ & $10(45.5)$ & $1(25)$ & $1(25.0)$ & $3(75.0)$ \\
H4 $=4$ & $3(75.0)$ & $1(20)$ & $1(20.0)$ & $4(80.0)$ \\
H5 $=5$ & $4(80.0)$ & $15(23.3)$ & $10(29.9)$ & $34(70.1)$ \\
Total & $29(76.7)$ & &
\end{tabular}

Note. ET = Emergency trolley. 
Table 2 presents the availability of drugs in emergency trolleys, recommended according to the priority level I and their validity. It was observed that the following drugs were available, with validity expired: the magnesium sulfate $(27.3 \%)$, furosemide $(15.9 \%)$, and sodium nitroprusside (13.6\%). Also found in smaller proportions were ampoules of atropine $(6.8 \%)$ and adrenaline (4.5\%). However, the unavailable drugs were procainamide (100\%), bronchodilators $(95.5 \%)$, and beta-blockers (93.2\%).
Regarding the recommended drugs of priority level II, it was found that dopamine showed $15.9 \%$ availability with expired validity, followed by dormonid/fentanyl (9.1\%) and diazepam (4.5\%). The unavailable drugs were aminophylline (100\%), morphine (93.2\%), and diazepam (90.9\%).

Also, the available priority level 3 drugs with expired validities were the solution of mannitol $9.1 \%$ and naloxone $4.5 \%$. The unavailable drugs were diltiazem (100\%), isoproterenol (100\%), and verapamil (97.7\%).

\section{Table 2}

\section{Distribution of drugs according to priority level, availability, and validity in emergency trolleys}

\begin{tabular}{|c|c|c|c|}
\hline \multirow{2}{*}{$\begin{array}{l}\text { Drugs } \\
\text { Priority level } 1\end{array}$} & \multicolumn{2}{|c|}{$\begin{array}{l}\text { ET with available medication } \\
\qquad \begin{array}{c}(n=44) \\
n(\%)\end{array}\end{array}$} & \multirow{2}{*}{$\begin{array}{c}\text { ET without medication } \\
\qquad(n=44) \\
n(\%)\end{array}$} \\
\hline & Within validity & Expired validity & \\
\hline Atropine $1 \mathrm{mg}$ & $41(93.2)$ & $3(6.8)$ & $0(0.0)$ \\
\hline Adrenaline $1 \mathrm{mg}$ & $41(93.2)$ & $2(4.5)$ & $1(2.3)$ \\
\hline Lidocaine & $38(86.4)$ & $0(0.0)$ & $6(13.6)$ \\
\hline Glucose $50 \%$ & $38(86.4)$ & $0(0.0)$ & $6(13.6)$ \\
\hline Calcium gluconate & $36(81.8)$ & $5(11.4)$ & $3(6.8)$ \\
\hline Furosemide & $28(63.6)$ & $7(15.9)$ & $9(20.5)$ \\
\hline Sodium bicarbonate & $26(59.1)$ & $4(9.1)$ & $14(31.8)$ \\
\hline Amiodarone & $25(56.8)$ & $4(9.1)$ & $15(34.1)$ \\
\hline Magnesium sulfate & $16(36.4)$ & $12(27.3)$ & $16(36.4)$ \\
\hline Adenosine & $11(25.0)$ & $0(0.0)$ & $33(75.0)$ \\
\hline Nitroprusside & $11(25.0)$ & $6(13.6)$ & $27(61.4)$ \\
\hline Nitroglycerin & $7(15.9)$ & $1(2.3)$ & $36(81.8)$ \\
\hline Beta-blocker & $3(6.8)$ & $0(0.0)$ & $41(93.2)$ \\
\hline Bronchodilator & $2(4.5)$ & $0(0.0)$ & $42(95.5)$ \\
\hline Procainamide & $0(0.0)$ & $0(0.0)$ & 44(100) \\
\hline Priority level 2 & Within validity & Expired validity & \\
\hline Dobutamine & $33(75.0)$ & $0(0.0)$ & $11(25.0)$ \\
\hline Dopamine & $30(68.2)$ & 7(15.9) & 7(15.9) \\
\hline Dormonid/Fentanyl & $12(27.3)$ & $4(9.1)$ & $28(63.6)$ \\
\hline Morphine & $3(6.8)$ & $0(0.0)$ & $41(93.2)$ \\
\hline Diazepam & $2(4.5)$ & $2(4.5)$ & 40(90.9) \\
\hline Aminophylline & $0(0.0)$ & $0(0.0)$ & $44(100.0)$ \\
\hline
\end{tabular}




\begin{tabular}{lccc}
\hline Priority level 3 & Within validity & Expired validity & \\
\hline Mannitol & $4(9.1)$ & $4(9.1)$ & $36(81.8)$ \\
Naloxone & $2(4.5)$ & $0(0.0)$ & $42(95.5)$ \\
Diltiazen & $0(0.0)$ & $0(0.0)$ & $44(100.0)$ \\
Verapamil & $0(0.0)$ & $1(2.3)$ & $43(97.7)$ \\
Isoproterenol & $0(0.0)$ & $0(0.0)$ & $44(100.0)$ \\
\hline
\end{tabular}

Note. ET = Emergency trolley.

Table 3 presents the non-standardized drugs available in the emergency trolleys. The following were classified as PDD: potassium chloride at $10 \%$, deslanoside, and sodium heparin in
$20.5 \%$. Also, some of these drugs showed expired validity, with emphasis on the deslanoside (9.1\%), followed by potassium chloride (19.1\%), promethazine, and phenobarbital (4.5\%).

Table 3

Distribution of potentially dangerous drugs according to availability and validity in emergency trolleys

\begin{tabular}{lccc}
\hline & \multicolumn{2}{c}{ ET with available PDD $(n=44)$} & $\begin{array}{c}\text { ET without PDD } \\
n(\%)\end{array}$ \\
\cline { 1 - 2 } PDD & Within validity & Expired valididty & $n(\%)$ \\
\cline { 1 - 2 } Potassium chloride 10\% & $9(20.5)$ & $0(0.0)$ & $35(79.5)$ \\
Deslanoside & $12(27.3)$ & $1(2.3)$ & $31(70.5)$ \\
Sodium heparin & $9(20.5)$ & $0(0.0)$ & $35(79.5)$ \\
Potassium chloride19.1\% & $7(15.9)$ & $2(4.5)$ & $35(79.5)$ \\
Suxamethonium chloride & $5(11.4)$ & $0(0.0)$ & $39(88.6)$ \\
Promethazine & $5(11.4)$ & $2(4.5)$ & $37(84.1)$ \\
Phenytoin & $4(9.1)$ & $2(4.5)$ & $38(86.4)$ \\
Glucose 10\% & $3(6.8)$ & $0(0.0)$ & $41(93.2)$ \\
Vasopressin & $0(0.0)$ & $6(13.6)$ & $38(86.4)$ \\
Phenobarbital & $0(0.0)$ & $1(2.3)$ & $43(47.7)$ \\
\hline
\end{tabular}

Note. $\mathrm{ET}=$ Emergency trolley; PDD = Potentially dangerous drugs.

\section{Discussion}

In this study, the lack of sealing in the majority of the emergency trolleys and their inadequate location were identified as aggravating factors that can contribute to the delay of the intervention in a CRA. The use of sealing and proper location of emergency trolleys for the control/ restocking of their items and their effective displacement are part of low-cost strategies that reduce adverse events (Pérez-García, Soria-Aledo, \& Collantes, 2016). The sealing of the emergency trolleys, in a study conducted in the United Kingdom, reduced the expired items in lack or excess, as well as the time spent their monitoring (Pérez-Garcia et al., 2016). A study conducted in Spain also found that the sealing of emergency trolleys reduced the excessive and improper storage of drugs (Bowden \& Smith, 2017). In both studies, items with a transparent bag sealing constitute barriers to prevent loan, inadvertent use, and excess, which could compromise the proper use of the items for their intended purposes. In this study, the 
sealing used was tamper-evident seals, which promote security in clinical practice in the use of emergency trolleys, when activated.

Although the location of emergency trolleys presented a lower percentage of non-conformity with the sealing, many of them were hidden between saline stands, beds, light focus, and the like, or even distant from beds, hindering their immediate visualization. This finding was also observed in a study conducted in Pernambuco, where emergency trolleys were poorly located (Reis \& Silva, 2016). The recommendation for intervention in a situation of CRA is that the trolleys should be located in an accessible location and not hidden or obstructed by any other material that harms their immediate displacement (Cid et al., 2017). It is understood that the improper location may delay and obstruct the intervention to the patient in CRA, compromising his/her prognosis. Thus, the health team should be aware of the location of the emergency trolleys because this knowledge affects the optimization of the response time of the administration of drugs.

Regarding the availability of drugs by priority level 1, 2 and 3, all emergency trolleys studied presented nonconformities, representing a possible error of the system that focuses directly on the patient's safety (Bowden $\&$ Smith, 2017). The lack of drugs in the emergency trolley, taking into account the priority level, becomes severe, especially in the case of adrenaline and atropine, which are drugs classified as priority level 1 and frequently used in CRA (Cid et al., 2017).

However, in addition to the lack of drugs, another aggravating factor observed stands out. There were some drugs with expired validity in all priority levels, with higher expression among the level 1. Like the findings of this study, a hospital in Botswana pointed to the need to maintain the availability of drugs within validity and ready to be used, since the intervention in the event of CRA is decisive for the patient's life (Rajeswaran \& Ehlers, 2012). In Britain, daily checks of all emergency trolleys are required, especially after their use, constituting itself as a security strategy as a barrier to prevent this type of grievance (Lo, Yu, Chen, Wang, \& Tang, 2013).

Thus, the Joint Commission on Accreditation of Healthcare Organizations (JCAHO), when analyzing the causes of medication errors in the United States of America, stated that the most common were the lack of professionals' training (65\%), poor communication between teams $(63 \%)$, inappropriate storage and access to medication $(26 \%)$, and the labeling thereof $(18 \%)$. It was noted that the inadequate storage of drugs was related to drugs with expired validity, in excess or lack; as well as uncontrolled psychotropic substances. These data corroborate the findings of this study and allow understanding that drugs with expired validity and absent in the emergency trolleys can contribute to medication errors.

For sure, the seriousness of the consequences related to the process, contributing to medication errors, shall determine the sanctions to the professional involved. First, the bodily injuries and the type of consequences for the patients need to be assessed; professionals may be subject to proceedings for negligence, imprudence, or incompetence, according to the civil, criminal land ethical law (Souza et al., 2018).

Only the materials essential to reverse a CRA are vital in the emergency trolley. Therefore, the accumulation of drugs hampers the accessibility to the correct drug (Bowden \& Smith, 2017). It is essential to highlight that, in the moment of a CRA, the rush and stress may promote medication errors when the drugs are not easily found. Thus, when it comes to the presence of non-standardized drugs, this study emphasized the severity of the presence of PDD, and, also, with validity expired.

It is recommended even that hospitals have an institutionally standardized list of PDD, as this management process is a priority in their dispensation, prescription, and administration. As a result, one can ensure that patients receive the correct medication, in the correct dosage and at the right time (Perini \& Anacleto, 2015). Thus, it is essential that the whole health team knows the risks of PDD and takes measures to minimize the occurrence of errors involving this group of drugs (Reis et al., 2018). Recent studies have indicated that there is lack of knowledge among health professionals, highlighting the existing gaps between the insertion of content on the topic of PDD in professional training, which must be solved through continuous and/or permanent education in health services (Reis et al., 2018). 
Thus, the Institute for Safe Medication Practices defines and updates each year a list of all high-alert drugs, with particular focus on adrenergic agonists and antagonists, antiarrhythmic drugs, antithrombotic drugs, opioids, sedatives, concentrated electrolytes, among others, for interdisciplinary disclosure (Perini \& Anacleto, 2015).

Studies that address the standardization of drugs in emergency trolleys are underdeveloped in Brazil, and, when approaching the CRA, they have a greater emphasis on resuscitation maneuvers and the use of equipment for its reversal. Therefore, this study reflects on safe practices related to the monitoring of emergency trolleys, particularly regarding the standardization, dispensing, and restocking of drugs through pre-established verification, according to institutional norms and routines. The criticality of the reality revealed in this study as to the excess of unavailable drugs, expired validities, and the presence of PDD confirms active flaws in the system, which contribute to the high exposure to risks of medication errors by the nursing team, as well as the reduction of the safety of care to the patient and the professional, serving as a warning and reflection to other institutions. It is suggested that the implementation of the sealing of emergency trolleys as a security barrier in the storage of drugs is an essential practice, as well as the effective communication between the nursing team/ pharmacists for the restocking of drugs after use. Although the nurse is responsible for checking the emergency trolleys, the continuous training of the team as to their responsibility for inspection and maintenance is directly associated with the effectiveness of care to the patient in CRA. Likewise, the dispensing and storage of MPP should be managed incisively, including the training of the health team.

This study presented significant limitations due to the lack of institutional standardization of hospitals involved in research in the amount and arrangement of drugs in the emergency trolley during data collection. Thus, institutional protocols, including training of the team, are practical barriers in reducing incidents that put at risk the patient's safety during the intervention in a CRA.

\section{Conclusion}

The standardization of drugs in emergency trolleys in ICU and A\&E does not follow the recommendation of the first Cardiopulmonary Resuscitation and Emergency Cardiovascular Care Guideline of the Brazilian Society of Cardiology, as evidenced by a lack of standardized drugs, expired validities, and availability of non-standardized PDD.

This fact may promote the occurrence of serious adverse events that impact the survival of the patient in CRA and judicial sanctions to the professionals involved. The nurse, through the implementation of healthcare protocols and processes, is the essential protagonist in the safety and qualification of the intervention to the patient when using the emergency trolley, as the responsibility of the health team is essential for the effective implementation of institutional goals.

\section{References}

Bowden, T., \& Smith, D. (2017). An overview of adult cardiopulmonary resuscitation equipment. Nursing Standard, 31(23), 54-63. doi: 10.7748/ns.2017. e10461

Cid, J. L., Núñez, R. A., Álvarez, A. C., Sarrato, G. Z., Fernández-Llamazares, C. M., \& Macíasf, C. C. (2017).

Recomendaciones de expertos sobre el material deli carro y mochila de reanimación cardiopulmonar pediátrica y neonatal. Anales de Pediatria, 88(3), 173.e1-173.e7. doi: 10.1016/j.anpedi.2017.05.010

Conselho Federal de Enfermagem. (2018). Ementa: Parecer técnico sobre conferêncialvistoria e reposição do carro de emergência (Parecer No 024/2018/COFEN/ CTAS). Retrieved from http://www.cofen.gov.br/ parecer-no-024-2018-cofen-ctas_67673.html

Conselho Regional de Enfermagem da Bahia. (2018). Assunto: Composição, responsabilidade pela montagem, conferência e reposiçáo do carro de emergência (Parecer No 006/2018). Retrieved from http://ba.corens. portalcofen.gov.br/wp-content/uploads/2018/06/ PT-006-2018-CARRO-DE-EMERGENCIA.pdf

Costa, D. G., Pasin, S. S., Magalhães, A. M., Moura, G. M., Rosso, C. B., \& Saurin, T. A. (2018). Análise do preparo e administração de medicamentos no contexto hospitalar com base no pensamento Lean. Escola Anna Nery, 22(4), 1-9. doi: 10.1590/21779465-EAN-2017-0402 
Davies, M., Couper, K., Bradley, J., Baker, A., Husselbee, N., Woolley, S., . . Perkins, G. D. (2014). A simple solution for improving reliability of cardiac arrest equipment provision in hospital. Resuscitation, 85(11), 1523-1526. doi: 10.1016/j.resuscitation.2014.07.021

Gonzalez, M. M., Timerman, S., Oliveira, R. G., Polastri, T. F., Dalan, L. A., Araújo, S., . . Favarato, M. H. (2013). I Diretriz de ressuscitação cardiopulmonar e cuidados cardiovasculares de emergência da Sociedade Brasileira de Cardiologia: Resumo executivo. Arquivos Brasileiros de Cardiologia, 100(2), 105-113. doi: $10.5935 /$ abc. 20130022

Lo, T. F., Yu, S., Chen, I. J., Wang, K. W., \& Tang, F. I. (2013). Faculties' and nurses' perspectives regarding knowledge of high-alert medications. Nurse Education Today, 33(3), 214-221. doi: 10.1016/j. nedt.2012.01.004

Mieiro, D. B., Oliveira, É. B., Fonseca, R. E., Mininel, V. A., Zem-Mascarenhas, S. H., \& Machado, R. C. (2019). Estratégias para minimizar erros de medicação em unidades de emergência: revisão integrativa. $R e-$ vista Brasileira de Enfermagem, 72(Supl. 1), 307-314. doi: 10.1590/0034-7167-2017-0658

Pérez-García, M. Del, Soria-Aledo, V., \& Collantes, F. (2016). Implementation and evaluation of the medication management in nursing units of a university hospital by means of a quality improvement cycle. Applied Nursing Research, 29, 148-156. doi: 10.1016/j.apnr.2015.05.012

Perini, E., \& Anacleto, T. A. (Coords.). (2015). Medicamentos potencialmente perigosos de uso hospitalar e ambulatorial - Listas atualizadas 2015. Boletim ISMP, 4(3), 1-8. Retrieved from http://biblioteca. cofen.gov.br/wp-content/uploads/2015/10/boletim_ISMP_32-Lista-atualizada.pdf

Rajeswaran, L., \& Ehlers, V. J. (2012). Audits of emergen- cy trolleys' contents in selected hospitals in Botswana. Health SA Gesondheid, 17(1), a621. doi: 10.4102/ hsag.v17i1.621

Reis, A. T., \& Silva, C. R. (2016). Segurança do paciente. Cadernos de Saúde Pública, 32(3), eRE020316. doi: 10.1590/0102-311XRE020316

Reis, M. A., Gabriel, C. S., Zanetti, A. C., Bernardes, A., Laus, A. M., \& Pereira, L. R. (2018). Medicamentos potencialmente perigosos: identificação de riscos e barreiras de prevenção de erros em terapia intensiva. Texto \& Contexto Enfermagem, 27(2), e5710016. doi: 10.1590/0104-07072018005710016

Silva, R. M., Silva, B. A., Silva, F. J., \& Amaral, C. F. (2016). Ressuscitação cardiopulmonar de adultos com parada cardíaca intra-hospitalar utilizando o estilo Utstein. Revista Brasileira de Terapia Intensiva, 28(4), 427-435. doi: 10.5935/0103-507x.20160076

Smith, A., Kinross, J., Bailey, M., Aggarwal, R., Toresen, D., \& Vincent, C. (2008). Re-stocking the resuscitation trolley: How good is compliance with checking procedures? Clinical Risk, 14(1), 4-7. doi: 10.1258/ cr.2007.070008

Souza, V. S., Inoue, K. C., Costa, M. A., Oliveira, J. L., Marcon, S. S., \& Matsuda, L. M. (2018). Nursing errors in the medication process: television electronic media analysis. Escola Anna Nery, 22(2), e20170306. doi: 10.1590/2177-9465-ean-2017-0306

Strzyzewski, N. (2006). Common errors made in resuscitation of respiratory and cardiac arrest. Plastic Surgical Nursing, 26(1), 10-16. doi: 10.1097/00006527200601000-00004

Valle, M. M., Cruz, E. D., \& Santos, T. (2017). Incidentes com medicamentos em unidade de urgência e emergência: análise documental. Revista da Escola de Enfermagem da USP, 51, e03271. doi: 10.1590/ s1980-220x2016033303271 
